\title{
Remote Sensing Applied to the Evaluation of Spatial and Temporal Variation of Water Quality in a Coastal Environment, Southeast Brazil
}

\section{Pedro Bettencourt ${ }^{1}$, Julio Cesar Wasserman ${ }^{1,2^{*}}$ (), Fábio Ferreira Dias ${ }^{3}$, Paulo Roberto Alves ${ }^{3}$, Dandara Bernardino Bezerra4, Camila Américo Santos5, Luis Perez Zotes', Sérgio Ricardo Barros ${ }^{1}$}

\author{
${ }^{1}$ Post-Graduate Program in Sustainable Systems Management, UFF, Niterói, Brazil \\ ${ }^{2}$ Post-Graduate Program in Geochemistry, UFF, Niterói, Brazil \\ ${ }^{3}$ Department of Geoenvironmental Analysis, UFF, Niterói, Brazil \\ ${ }^{4}$ Pós graduação em Biologia Marinha e Ambientes Costeiros, UFF, Niterói, Brazil \\ ${ }^{5}$ Pós graduação em Engenharia de Biossistemas, UFF, Niterói, Brazil \\ Email: ^geowass@vm.uff.br
}

How to cite this paper: Bettencourt, P., Wasserman, J.C., Dias, F.F., Alves, P.R., Bezerra, D.B., Santos, C.A., Zotes, L.P. and Barros, S.R. (2019) Remote Sensing Applied to the Evaluation of Spatial and Temporal Variation of Water Quality in a Coastal Environment, Southeast Brazil. Journal of Geographic Information System, 11, 500-521.

https://doi.org/10.4236/jgis.2019.115031

Received: August 19, 2019

Accepted: October 8, 2019

Published: October 11, 2019

Copyright $\odot 2019$ by author(s) and Scientific Research Publishing Inc. This work is licensed under the Creative Commons Attribution International License (CC BY 4.0).

http://creativecommons.org/licenses/by/4.0/ c) (i) Open Access

\begin{abstract}
The monitoring of water quality in large coastal regions demands great analytical efforts through the collection of many samples, over long periods. Remote sensing is a reliable tool that can provide valuable information on the spatial and temporal variations of environmental parameters, particularly turbidity and chlorophyll a. The aim of the present research was to evaluate the spatial and temporal distribution of water quality from 2005 to 2017 along the north coast of São Paulo and its responses to the implementation of industrial developments and to variations in rainfall. Fifty-two MODIS images were used, showing concentrations of chlorophyll a and turbidity, in the dry season and wet season, from 2005 to 2017. The results showed that dilution processes (due to rainfall) control chlorophyll a concentrations. However, a notable increase in concentrations could be identified after the installation of some of the developments in the region, particularly roads and ports. Turbidity was also shown to be affected by dilution processes, and during the wet season this parameter presented lower values. No effect in the results of turbidity could be identified from the installation of roads or ports, showing that vegetation cover exerts an important control on the erosional processes.
\end{abstract}

\section{Keywords}

Water Quality, Chlorophyll a, Turbidity, MODIS, Remote Sensing 


\section{Introduction}

Long-term monitoring programs can provide information on water-quality changes caused by population growth, large infrastructure projects, and increased industrial activity [1] [2]. These anthropogenic activities may surpass the loading capacity of a system, resulting in environmental degradation. Yet, in order to be effective, monitoring programs need to be carefully designed and thorough. Simply drawing samples from a system does not always take spatial variations into account, and interpolation frequently fails to give a realistic or comprehensive picture of the spatial processes [3]. To overcome these pitfalls, remote sensing techniques have proved useful, to fill in the gaps between sampling sites [4].

The application of remote sensing to evaluate water quality began in the early 1970s, and was based on the concept that light backscattering changes as a function of the presence of different substances in the water [5] [6]. Later, Miller, Cruise [4] showed that the application of algorithms to the strength of the remote sensor signals, pixel by pixel, would allow the quantification of the amount of suspended particulate matter in the water. In their work, they were able to calibrate the values with simultaneous measurements, using oceanographic procedures. Following on their work, international cooperation efforts like the Ocean Color European Archive Network (the OCEAN project) [7] were shown to be useful in the identification of relationships between water components and remote sensor signals.

The validation of remote sensing data has been the subject of various research programs (e.g.: Hakvoort, de Haan [8]), showing that in many situations, concentrations of phytoplankton pigments and turbidity could be adequately estimated from multi-band satellite images. Many different satellite sensors have been used for the purpose of estimating water quality; for example, various versions of the Landsat satellite system have been applied [9] [10] [11]. But the most commonly used sensor is MODIS (Moderate Resolution Imaging Spectroradiometer), installed aboard the Terra and Aqua satellites; it is capable of obtaining enough images to cover the entire surface of the earth every one or two days [12] [13]. The main limitation of MODIS is its resolution (images consist of 250-m pixels), which, although suitable for many large-scale applications [14], is not always sufficient for more detailed studies. Recently, however, $\mathrm{Fu}, \mathrm{Xu}$ [15] showed that, depending on the needed scale, MODIS images can be spatially downscaled with Landsat 8 images.

Yet, aside from the importance of producing extended series of temporal and spatial data, what matters most is the interpretation of these various images of water quality. The relationship between anthropogenic inputs and water quality is not as direct as one might expect. Local water currents and rainfall patterns can significantly affect the behavior of the plumes of rivers draining populated areas [16]. There are only a few works that consider these spatio-temporal evolutions of the water quality considering rainfall [12] [17] [18] and we could 
not identify any work relating water quality, rainfall and large dimension developments in the drainage basin altogether.

An earlier study [19] evaluated variations in the water quality of a small drainage basin in Southeast Brazil, and observed the extreme influence of one rainfall event, but hourly sampling showed that early in the morning, when local inhabitants had not yet begun their daily activities, human inputs were insignificant. Later in the day, human-induced inputs increased. Then, at night, water quality improved again. These authors showed that the rapid response of the water system to human activities was attributable to the small size of the drainage basin (a few square kilometers), where heavy rains promote immediate increase in discharge rates. It is also interesting to note that, in addition to drainage basin size, drainage network structure, spatial distribution of land use, basin storage capacity in urban and rural soils, and storm-water retention ponds also influence the discharge rates [20], which in turn affect the water quality of the ocean just off the coast. Nevertheless, the amount of rain in a drainage basin always exerts a heavy influence on water quality, and graphs of monthly or weekly rainfall patterns are extremely useful for supplementing water-quality data from remote sensing images.

In the present research, the evolution of the water quality along the northern coast of São Paulo State, Brazil, was evaluated based on satellite (Acqua) images (MODIS) from 2005 to 2017, taking into account the additional influence of large infrastructure projects recently constructed in the region (since 2005), population increases, and rainfall events. The association of these parameters as explaining elements for the water quality determined by satellite images is a new approach for a better understanding of the factors that control concentrations of chlorophyll a and turbidity. Regardless the fact that images provide 35 spectral bands that are capable of displaying a number of water quality parameters, these two elements were chosen as indicators, because they are good indicators and, because they are reliably mapped from satellite images.

\section{Materials and Methods}

\subsection{The Study Area}

The north coast of São Paulo State is located some $170 \mathrm{~km}$ ESE from the city of São Paulo and comprises the municipalities of São Sebastião, Ilhabela, Caraguatatuba and Ubatuba (Figure 1). The main geomorphologic feature of the region is the Sea Range, a mountain chain that stretches west to east, close to the coast, restricting drainage basins to a few kilometers in length. Near the ocean, the narrow coastal flats comprise urban areas, while the steep inland hills are densely covered with Atlantic Forest vegetation. The geology of the whole region was described by Suguio and Martin [21], characterizing the Sea Range as Precambrian and Cretacean crystalline intrusive rocks. The coastal plain, whose elevation does not exceed 70 meters, is filled with sand and mud originating in the Marine Holocene and Pleistocene. Mangrove and recent wetland sediments are associated with fluvio-lagoon and embayment sands and muds. 


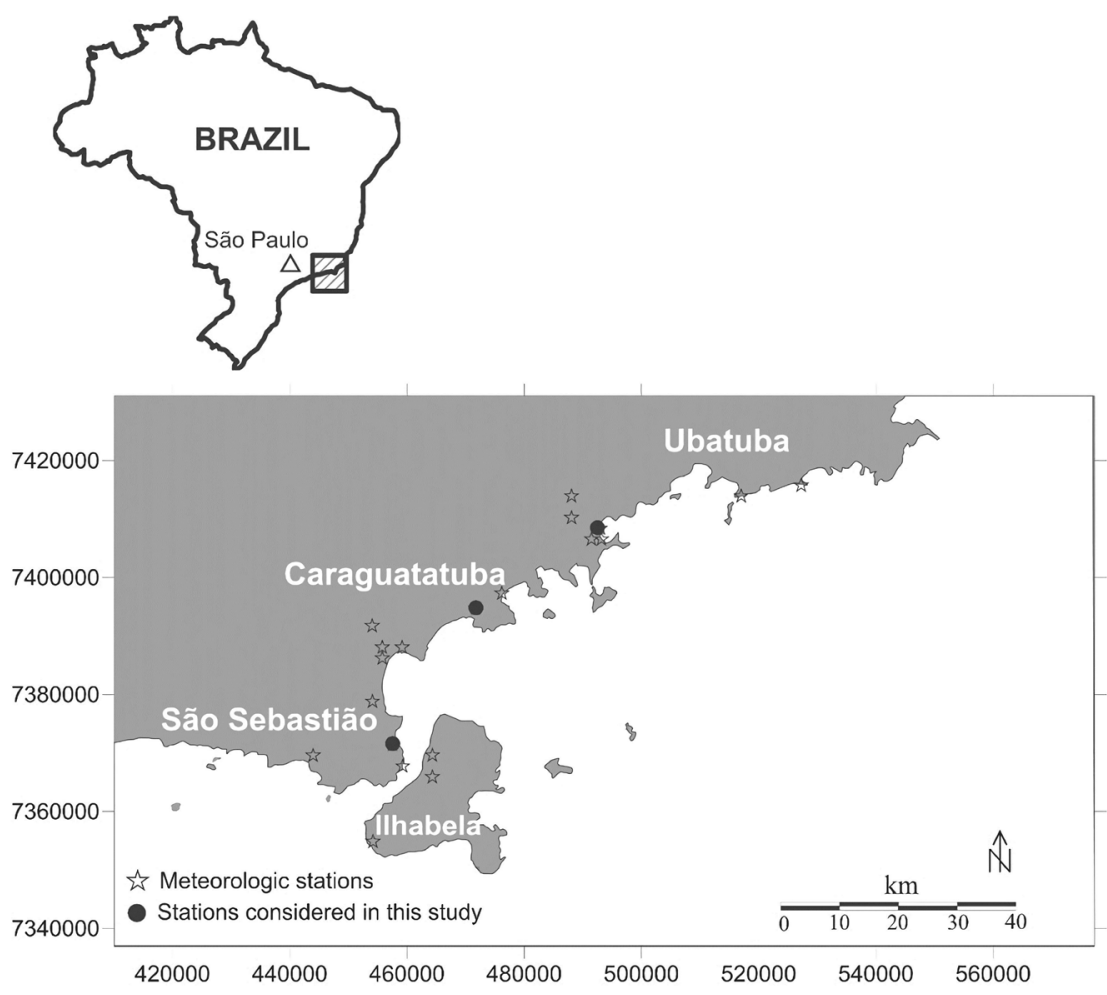

Figure 1. Location of the study area, indicating the 4 municipalities of the coastal region. Stars represent the meteorological stations whose data were used to construct an isohyet map. Black circles indicate stations whose data were used to construct the pluviometry graphs.

Because of access limitations, human occupation of the north coast of São Paulo was not prioritized during the nineteenth or twentieth centuries. However, near the end of the 1960s, the construction of the maritime terminal Tebar in the city of São Sebastião led to fast-paced industrial development in that city. In the early 1980s the SP-55 road (presently BR-101) was constructed, creating easy land transportation access to the area [22]. The well-preserved forest and attractive recessed beaches drew tourism activity, and the area began to be significantly developed for recreation, mainly in Ilhabela and Ubatuba [23], causing conflicts with the industries and petroleum facilities that had recently been installed.

The petroleum industry in the region is mainly associated with offshore pre-salt exploration and may generate significant impacts on this very ecologically sensitive territory-similar to what occurred in the region of Macaé (North of Rio de Janeiro State), where degradation of the socio-environmental structure was reported by Binsztok and colleagues [24] [25]. These activities, together with the development of maritime terminals and ports and transportation improvements (since 2005) are reported in Table 1. The activities reported here are not the only ones that have impacted the region, but were selected for this study based on two criteria: 1) the activities are located along the coastline, or significantly impact the coastal areas; and 2) financial investment has exceeded 250 million dollars. For every development depicted in Table 1, a relevant impact 
Table 1. Large new developments installed along the north coast of São Paulo (since 2005) that have significantly impacted the area. The developments are divided into petroleum facilities (onshore and offshore), terminals and ports, and transportation facilities.

\begin{tabular}{|c|c|c|}
\hline Development & Description & $\begin{array}{l}\text { Commencement } \\
\text { of activity }\end{array}$ \\
\hline $\begin{array}{l}\text { Platform and underwater pipeline from } \\
\text { Mexilhão Field }\end{array}$ & Offshore-Gas and condensed gas production from Mexilhão field, Santos Basin & February 2007 \\
\hline TLDs Guará & $\begin{array}{l}\text { Offshore-Long-term testing in the offshore petroleum fields of Guará, Carioca, } \\
\text { Tupi and Iracema, Santos Basin }\end{array}$ & September 2009 \\
\hline $\begin{array}{l}\text { Pilot production test in the field of } \\
\text { Tupi/Lula }\end{array}$ & $\begin{array}{l}\text { Offshore-Pilot production and outflow of petroleum and gas from the field of } \\
\text { Tupi, Santos Basin. }\end{array}$ & September 2008 \\
\hline $\begin{array}{l}\text { Exploration and development projects } \\
\text { of the pre-salt in the Santos Basin }\end{array}$ & $\begin{array}{l}\text { Offshore/onshore-integrated projects of production and outflow of petroleum } \\
\text { and natural gas from the pre-salt }\end{array}$ & November 2011 \\
\hline UTGCA & Onshore-Caraguatatuba gas treatment unit & April 2006 \\
\hline GASTAU & Onshore-Gas pipeline Caraguatatuba-Taubaté & April 2006 \\
\hline New pier-TEBAR & $\begin{array}{l}\text { Terminals and ports-Enlargement of a petroleum pier in the terminal of São } \\
\text { Sebastião }\end{array}$ & September 2011 \\
\hline Enlargement of the São Sebastião Port & $\begin{array}{l}\text { Terminals and ports-Enlargement of the São Sebastião Port and its integration } \\
\text { with the city }\end{array}$ & October 2009 \\
\hline $\begin{array}{l}\text { Nova Tamoios Highway sub-track } \\
\text { upland }\end{array}$ & $\begin{array}{l}\text { Transportation facilities-duplication of the Tamoios Highway in the upland } \\
\text { region }\end{array}$ & August 2011 \\
\hline $\begin{array}{l}\text { Nova Tamoios: sub-track southern } \\
\text { contours }\end{array}$ & $\begin{array}{l}\text { Transportation facilities-Construction of the southern contours of the Tamoios } \\
\text { Highway linking Caraguatatuba and São Sebastião }\end{array}$ & February 2010 \\
\hline $\begin{array}{l}\text { Nova Tamoios: sub-track northern } \\
\text { contours }\end{array}$ & $\begin{array}{l}\text { Transportation facilities-Construction of the northern contours of the Tamoios } \\
\text { Highway north of Caraguatatuba }\end{array}$ & December 2011 \\
\hline
\end{tabular}

might be expected. Regional population growth was significant in the decades of the 1990s and 2000s, reaching $44 \%$ in the former period and $22 \%$ in the second [26].

\subsection{Pluviometric Survey}

Rainfall data were obtained from various meteorological stations within the region (stars in Figure 1) reported in the National Agency of Waters (ANA-Hidroweb), enabling the construction of an isohyet map of rainfall distribution. Three meteorological stations (black circles in Figure 1) were selected to analyze the variations during the period 2005-2017. No station in the municipality of Ilhabella was included because they were all located very close to the São Francisco Station in the Municipality of São Sebastião. Rainfall was displayed in monthly line graphs to give a better overview of the variations within this period.

\subsection{Chlorophyll a and Turbidity from Satellite Imagery}

Satellite images were obtained every year, from 2005 until 2018, in the summer (December-March; wet season) and in the winter (June-September; dry season) from the sensor MODIS (Moderate Resolution Imaging Spectroradiometer), in- 
stalled in the satellite Aqua (originally known as EOS PM-1). The acquired images provide 35 spectral bands that can be treated to evaluate many aspects of the surface of the water, including concentrations of chlorophyll a and water turbidity. These images were obtained from the site "Ocean Color Browse" (https://oceancolor.gsfc.nasa.gov/cgi/browse.pl?sen=am). Images displaying chlorophyll a concentrations and water turbidity in a day with little cloud cover were chosen for each period, downloaded and analyzed using the software "SeaDAS7.4". The final maps were prepared in the environment "ArcMap" using the software "ARCGIS 10.2". In the summers of 2007 and 2012, the images were inadequate (due to cloud cover) and could not be used.

\section{Results and Discussion}

\subsection{Climatic Conditions during the Study}

De Souza Rolim, Paes de Camargo [27] showed that the climate in the north coast area of São Paulo is tropical, with extremely wet summers and dry winters (type Am, after the classification of Köppen). The average rainfall over 70 years of measurements at the São Francisco Station (São Sebastião; black circle in Figure 1) was $1197.1 \mathrm{~mm}$, while at the CEEPAM station (Caraguatatuba; black circle in Figure 1), the value was $2027.9 \mathrm{~mm}$ and in Ubatuba (black circle in Figure 1), it was 2253.6. This significant southwest-to-northeast rainfall gradient is represented in the isohyet map (Figure 2). These differences are probably associated with orographic processes, because the elevated areas in the northeast are steeper than those in the southeast. It has to be emphasized that vegetation cover in the north is denser, and higher pluviosity should not result in higher concentrations of suspended matter (turbidity), as will be discussed further here.

The results of monthly rainfall data from 2005 to 2017 are represented in the graphs of Figure 3, for the stations São Francisco (São Sebastião), CEEPAM (Caraguatatuba) and Ubatuba (Ubatuba). It is possible to identify periods of very

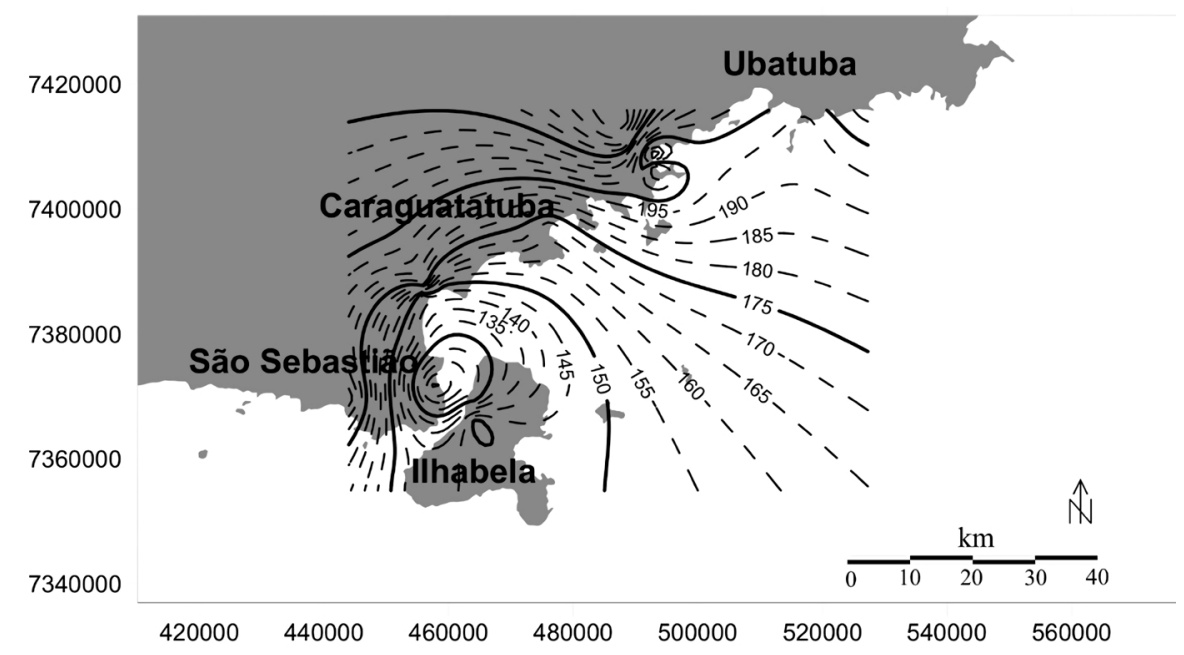

Figure 2. Annual isohyet map of the north coast of São Paulo. Lines represent monthly average values. Data from all meteorological stations reported in Figure 1 were considered. 

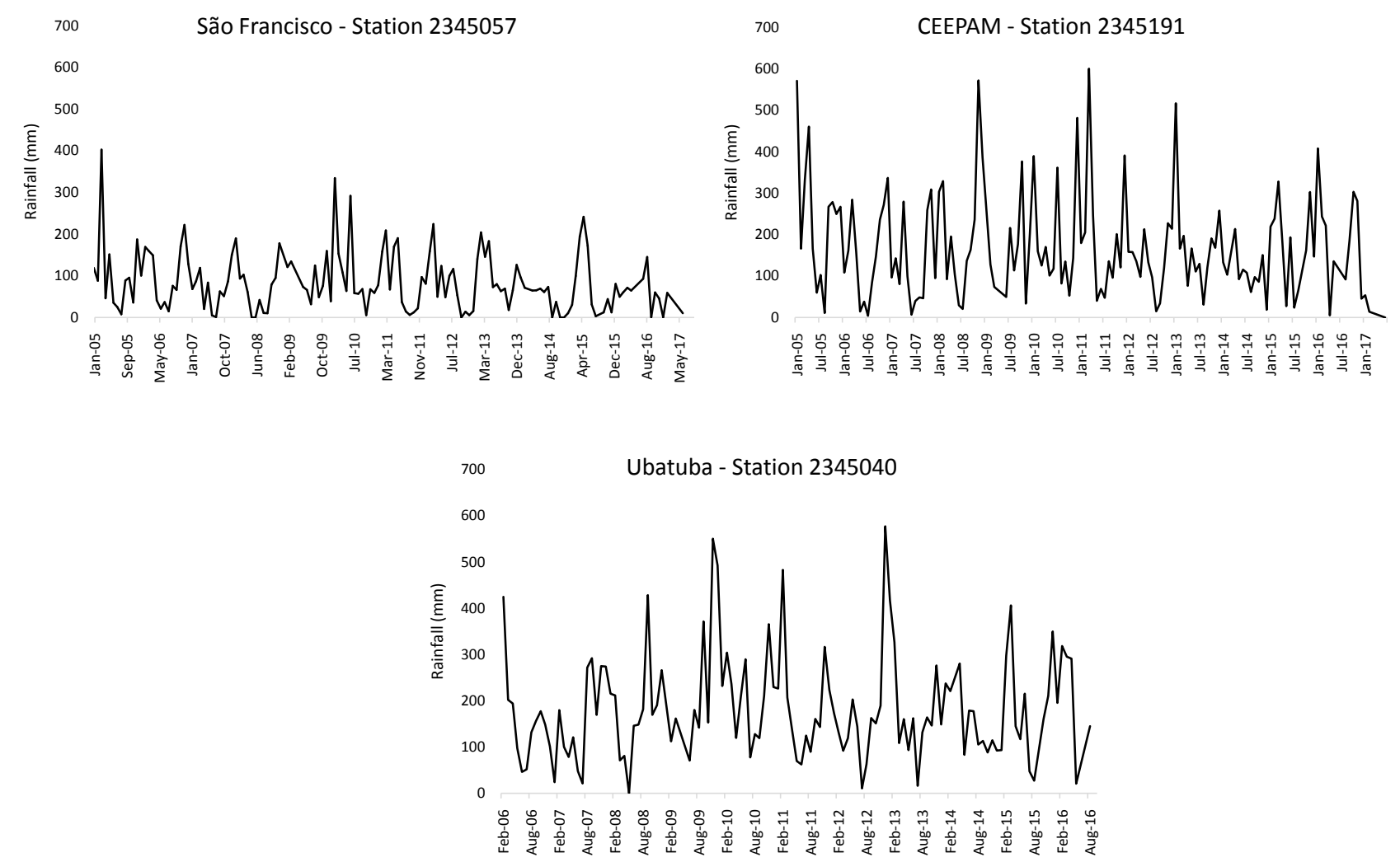

Figure 3. Monthly variation in rainfall during the period 2005-2017 in the stations of São Francisco (municipality of São Sebastião), CEEPAM (municipality of Caraguatatuba) and Ubatuba (municipality of Ubatuba). See Figure 1 for the position of each station (black circles).

strong rainfall activity during the summers of 2011 and 2013 in the stations CEEPAM (Caraguatatuba) and Ubatuba. During the spring of 2009 and the summer of 2011 very high values were registered in Ubatuba. High values were also observed in CEEPAM (Caraguatatuba) in October 2008. The highest monthly values for the municipalities of Caraguatatuba and Ubatuba reached $500 \mathrm{~mm}$, while in São Sebastião, the highest values never exceeded $400 \mathrm{~mm}$. The years 2009, 2010, 2011 and 2013 also registered excessive rainfall in other areas of southeast Brazil; these were probably associated with more intense El Niño phenomena [28].

\subsection{Chlorophyll a and Turbidity in the North Coast Area of São Paulo}

In the present work 26 images (dry and wet seasons from 2005 to 2017 inclusive) were prepared, displaying the parameter chlorophyll a, with another 26 images displaying the parameter turbidity. A complementary sample set of images is presented in the appendix A (A1 to A9).

Among the parameters that may control intensity of chlorophyll a production, the provision of nutrients is relevant and associated with wet-season (summer) tourism activity in the region [29]. Sunlight incidence is also important for primary chlorophyll a production and is expected to be more intense in the wet 
season (summer). On the other hand, the transparency of the water is very important because less turbid water allows more light to penetrate, increasing water primary production [30], so that in the dry season (winter), although lower nutrient concentrations are expected, higher primary production may result from water transparency. Finally, higher volumes of water entering the system (as in the wet season) may dilute concentrations of chlorophyll a [19].

For chlorophyll a, the analysis of the whole image sequence (since 2005) indicates that in the wet season primary production is less intense than in the dry season (Figure 4 shows the dry and wet seasons for the year 2010). This behavior indicates that although the provision of nutrients and the intensity of sunlight are expected to be higher during the wet season (summer), it is probable that strong water dilution hinders primary production. In Figure 3, for all stations, it can be observed that the dry-period (from May to September) rainfall is about one third that of the wet-period amounts. However, Figure 5 shows that

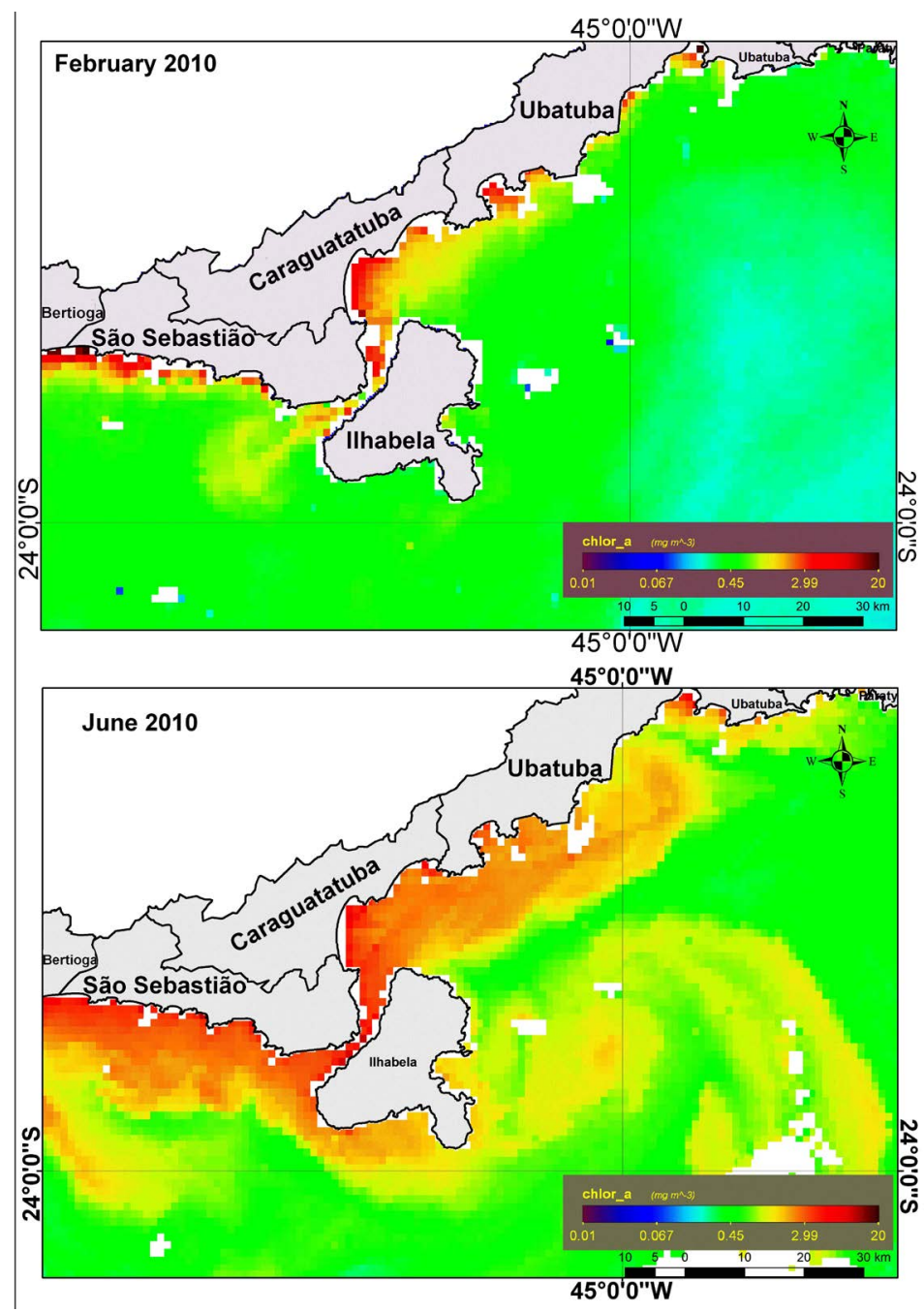

Figure 4. Chlorophyll a concentration (in $\mathrm{mg} \cdot \mathrm{m}^{-3}=\mu \mathrm{g} \cdot \mathrm{L}^{-1}$ ) along the north coast of São Paulo. Image on left is from the wet season (February) of 2010 and image on right from the dry season (June) of 2010. 


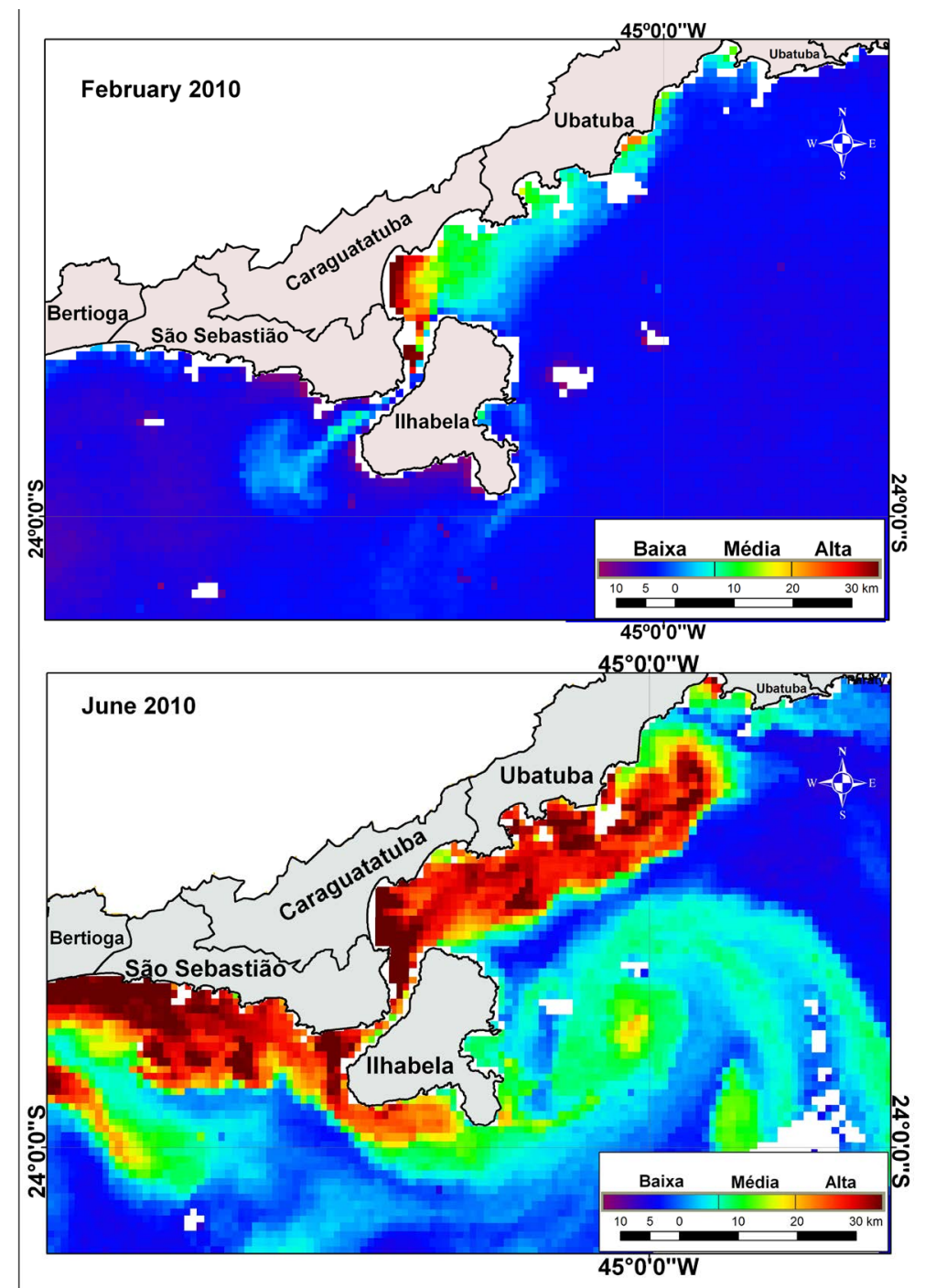

Figure 5. Turbidity (qualitative approach) along the north coast of São Paulo. Image on left is from the wet season (February) of 2010 and image on right from the dry season (June) of 2010.

the results of turbidity (also for the year 2010) did not show the expected higher values during the wet season, indicating that dilution from higher rainfall is more important than other influences. This trend was similar for all the other years.

For a temporal evolution of the concentrations of chlorophyll a and turbidity (2005-2017), besides rainfall, we considered the major development projects in the region and their impacts. Table 2 depicts the impact of each development and the estimated intensity at the qualitative scale (irrelevant, light, mild, strong and very strong). From Table 2, it is possible to identify the period between 2009 and 2011 as the beginning of the most impacting development. It must be emphasized that the development did not stop in 2011, because the roads and harbors have continued to produce suspended matter (from removed vegetation) and nutrient elements (from population increase). The intensification of the 
Table 2. Main impacts of development projects, their intensities and the periods when the activity began.

\begin{tabular}{|c|c|c|c|}
\hline Development & Aspects/Impacts [33] & $\begin{array}{l}\text { Intensity } \\
\text { of impact }\end{array}$ & $\begin{array}{l}\text { Commencement } \\
\text { of activity }\end{array}$ \\
\hline $\begin{array}{l}\text { Platform and underwater pipeline } \\
\text { from Mexilhão Field }\end{array}$ & Dredging and underwater movements/offshore resuspension of sediments & Irrelevant & February 2007 \\
\hline Long-Term Testing Guará & Dredging and underwater movements/offshore resuspension of sediments & Irrelevant & September 2009 \\
\hline $\begin{array}{l}\text { Pilot production test in the field of } \\
\text { Tupi/Lula }\end{array}$ & $\begin{array}{l}\text { Dredging and underwater movements/offshore resuspension of sediments; } \\
\text { intensification of naval activity along the coast }\end{array}$ & Light & September 2008 \\
\hline $\begin{array}{l}\text { Exploration and development } \\
\text { projects of the pre-salt in the } \\
\text { Santos Basin }\end{array}$ & Dredging and underwater movements/offshore resuspension of sediments & Irrelevant & November 2011 \\
\hline UTGCA-Gas treatment unit & $\begin{array}{l}\text { Vegetation removal, landfilling, population increase/degradation of the } \\
\text { landscape }\end{array}$ & Mild & April 2006 \\
\hline GASTAU_-Gas pipeline & $\begin{array}{l}\text { Vegetation removal, landfilling, population increase/degradation of the } \\
\text { landscape }\end{array}$ & Mild & April 2006 \\
\hline New pier-TEBAR & $\begin{array}{l}\text { Dredging and underwater movements; intensification of naval activity } \\
\text { along the coast, population increase/sediment resuspension, noise, } \\
\text { emissions, degradation of water quality }\end{array}$ & Mild & September 2011 \\
\hline $\begin{array}{l}\text { Enlargement of the São Sebastião } \\
\text { Port }\end{array}$ & $\begin{array}{l}\text { Dredging and underwater movements; intensification of naval activity } \\
\text { along the coast, population increase/sediment resuspension, noise, } \\
\text { emissions, degradation of water quality }\end{array}$ & Strong & October 2009 \\
\hline $\begin{array}{l}\text { Nova Tamoios Highway sub-track } \\
\text { upland }\end{array}$ & $\begin{array}{l}\text { Vegetation removal, landfilling, population increase (distant from the } \\
\text { coast)/degradation of the landscape; degradation of the water quality. }\end{array}$ & Strong & August 2011 \\
\hline $\begin{array}{l}\text { Nova Tamoios: sub-track Southern } \\
\text { Contours }\end{array}$ & $\begin{array}{l}\text { Vegetation removal, landfilling, population increase (near the } \\
\text { coast)/degradation of the landscape; degradation of water quality. }\end{array}$ & Very strong & February 2010 \\
\hline $\begin{array}{l}\text { Nova Tamoios: sub-track } \\
\text { Northern Contours }\end{array}$ & $\begin{array}{l}\text { Vegetation removal, landfilling, population increase (near the } \\
\text { coast)/degradation of the landscape; degradation of water quality. }\end{array}$ & Very strong & December 2011 \\
\hline
\end{tabular}

production of chlorophyll a is clearly verifiable from the images in the dry seasons of 2007 and 2012 (Figure 6), indicating a population increase as the source of increased inputs of nutrients. Observations from all the years, sampled in the Supplementary Material, clearly corroborate this trend. However, the year 2017 was an exception, when the concentrations significantly decreased. Based on the parameters we considered in this article, it is not possible to explain this phenomenon environmental improvement. Considering that the images are instantaneous pictures of the different situation, it is possible that other factors like exceptional oceanic currents (not considered in the present article) influenced water quality in the year 2017. Although there is no indications of the presence of oceanic waters in the study area, Paloczy, Brink [31] observed the intrusion of the South Atlantic Central Water (SACW) om the continental shelf of the Espirito Santo Basin, farther North of the study area.

Turbidity did not show the same trends as chlorophyll a; there was no significant evolution in the concentrations, with the development along the north coast of São Paulo. Some years, such as 2005, presented high turbidity during the dry season, but in the dry season of 2013 (Figure 7), after the installation of some of 


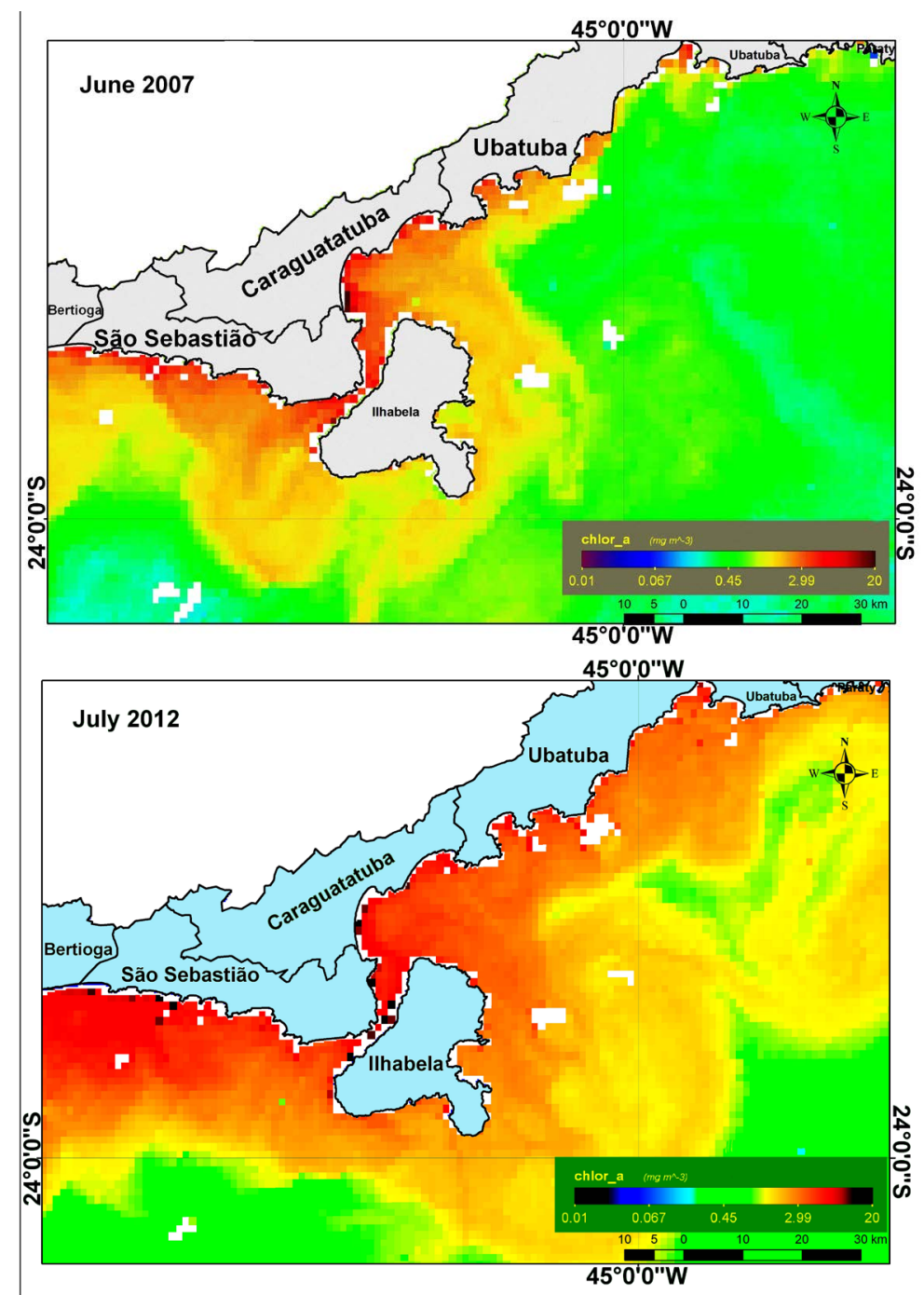

Figure 6. Chlorophyll a concentration (in $\mathrm{mg} \cdot \mathrm{m}^{-3}=\mu \mathrm{g} \cdot \mathrm{L}^{-1}$ ) along the north coast of São Paulo. Image on left is from the dry season of 2007 (June) and image on right from the dry season (July) of 2012 .

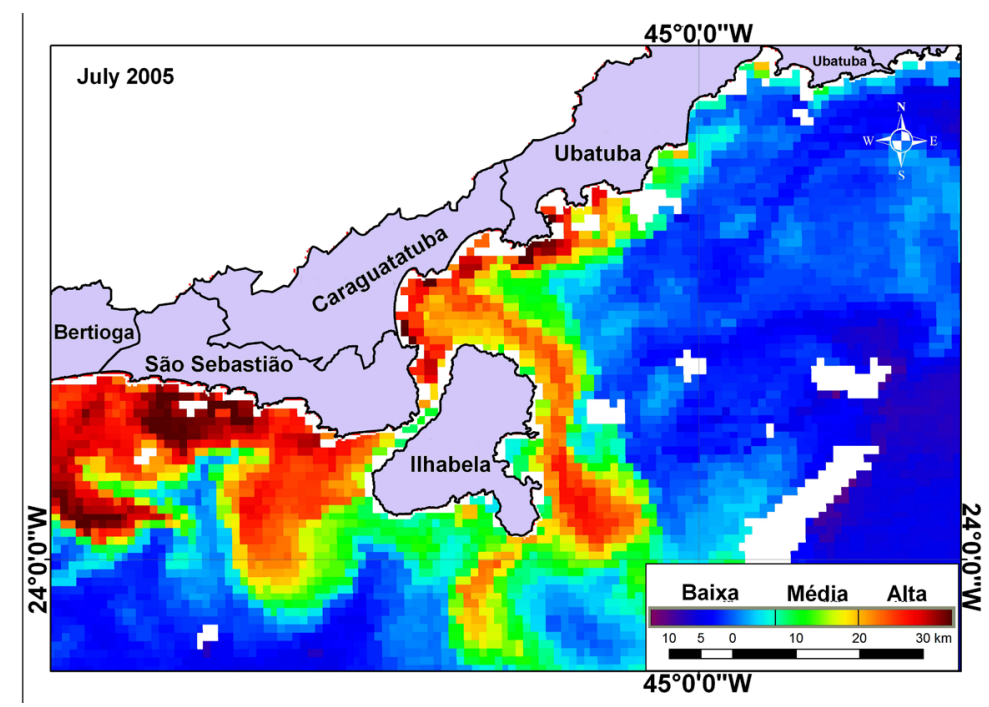




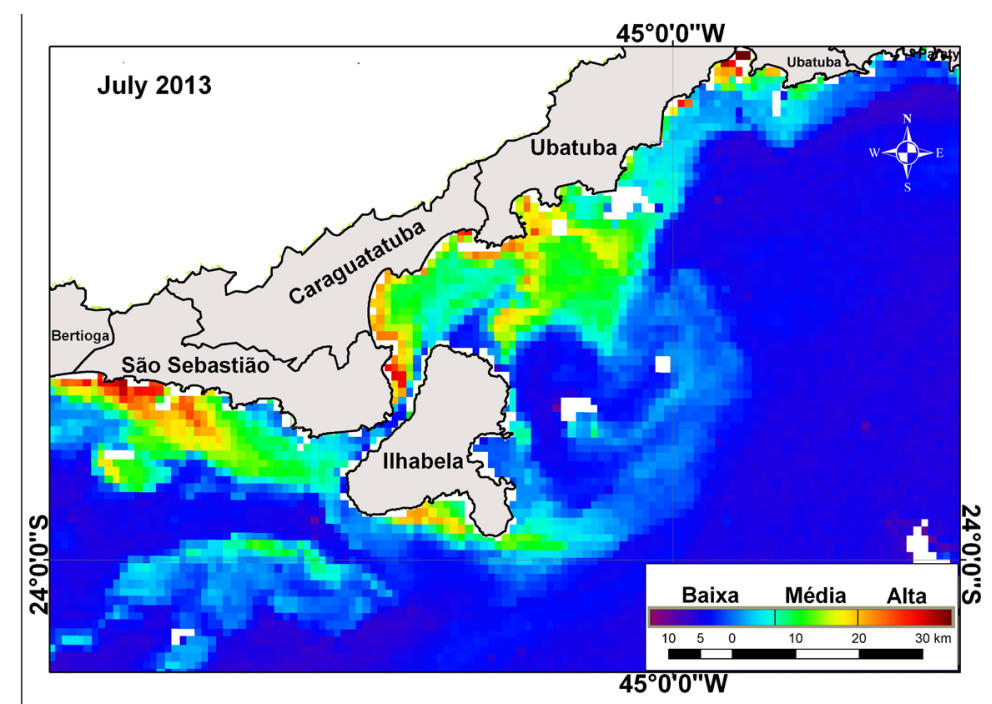

Figure 7. Turbidity (qualitative approach) along the north coast of São Paulo. Image on left is from the dry season (July) of 2005 and image on right from the dry season (July) of 2013.

the most impacting development, the turbidity was low. It is probable that, regardless of whether the most impacting development promoted the resuspension of sediments and the intensification of erosion in the continent, the region presented a well-preserved vegetation cover, particularly in the eastern portion [32]. This vegetation cover hinders any long-term increase in turbidity in the region.

\section{Conclusions}

Various parameters seem to control chlorophyll a in the water column of the north coast of São Paulo including provision of nutrients (associated with population increase and tourism). The transparency (depending on turbidity) of the water also contributes to the primary production by increasing the intensity of sunlight incidence also depending on the season. The volume of rainwater entering the system that promotes dilution of the concentrations also seems to be important. The occurrence of higher concentrations of chlorophyll a in the dry season (winter) is unexpected, because this period has less tourism activity, less incidence of sunlight and higher turbidity. Therefore, the dilution promoted by intense rainfall during the wet season (summer) is more effective in reducing primary production than all the other parameters, along the north coast of São Paulo.

The temporal evolution of the concentrations of chlorophyll a (2005-2017) shows that impacting developments like the construction and maintenance of roads and the installation or upgrade of ports promote population growth and increases in maritime activity. These impacting events, which were intensified after 2009, resulted in increasing chlorophyll a concentrations along the north coast of São Paulo. To mitigate the impacts, developments like these should be accompanied by extensive sanitation works, to reduce the load of nutrients. 
Images of turbidity along the north coast of São Paulo show that dilution from heavy rainfall in the wet season (summer) also controls this parameter in the water column. Most of the images show a higher turbidity in the dry season (winter) than in the wet season (summer), except for the years 2005 and 2009. Nevertheless, no temporal trends in turbidity could be observed from 2005 to 2017. After the installation of the most impacting developments during 2009-2011 no consistent or relevant increase in turbidity could be identified. Apparently, the preservation of the vegetation cover along the north Coast of São Paulo, and particularly in the eastern portion of the region, hinders increases in turbidity due to impacting developments like dredging and landfilling.

Finally, it is interesting to highlight some limitations of the research. First, although satellite images of the chlorophyll a and turbidity have been largely calibrated in many studies, the fact that we did not calibrate the results with real samples is a limitation, because the color response of the images may be different in distinct locations. Second, the interpretation of the results with other parameters like position of oceanic waters may be important, as discussed on the results of the year 2017. Unfortunately, the temporal behavior of oceanic currents in the southeast Brazil is poorly known and further studies are necessary. Third, it would be very helpful to compare the results of images with other biogeochemical parameters, like salinity, $\mathrm{pH}$, redox potential, dissolved oxygen and freshwater discharges. Some of these parameters like salinity can also be estimated by satellite imaging, while others have to be measured in situ.

\section{Acknowledgements}

The authors are grateful to Nemus Ltd. for financial support. JCW is also grateful to the Brazilian Council of Scientific and Technological Development (CNPq) for a research grant (grant \# 306714/2013-2). PB is also grateful to CAPES for financial support (grant \# 001). These financial supports do not imply any sort of bias in the results or their interpretation.

\section{Conflicts of Interest}

The authors declare no conflicts of interest regarding the publication of this paper.

\section{References}

[1] Kohli, P., Siver, P.A., Marsicano, L.J., Hamer, J.S. and Coffin, A.M. (2017) Assessment of Long-Term Trends for Management of Candlewood Lake, Connecticut, USA. Lake and Reservoir Management, 33, 280-300. https://doi.org/10.1080/10402381.2017.1335812

[2] Paterson, A.M., Ruhland, K.M., Anstey, C.V. and Smol, J.P. (2017) Climate as a Driver of Increasing Algal Production in Lake of the Woods, Ontario, Canada. Lake and Reservoir Management, 33, 403-414. https://doi.org/10.1080/10402381.2017.1379574

[3] Davis, T.W., Stumpf, R., Bullerjahn, G.S., McKay, R.M.L., Chaffin, J.D., Bridgeman, 
T.B., et al. (2019) Science Meets Policy: A Framework for Determining Impairment Designation Criteria for Large Waterbodies Affected by Cyanobacterial Harmful Algal Blooms. Harmful Algae, 81, 59-64. https://doi.org/10.1016/j.hal.2018.11.016

[4] Miller, R.L., Cruise, J.F., Otero, E. and Lopez, J.M. (1994) Monitoring Suspended Particulate Matter in Puerto-Rico-Field-Measurements and Remote Sensing. Journal of the American Water Resources Sources Association, 30, 271-282. https://doi.org/10.1111/j.1752-1688.1994.tb03290.x

[5] Kirk, J.T.O. (1994) Light and Photosynthesis in Aquatic Ecosystems. 2nd Edition, Cambridge University Press, Cambridge. https://doi.org/10.1017/CBO9780511623370

[6] Jerlov, N.G. (1976) Marine Optics. Elsevier Oceanography Series, Elsevier, Amsterdam, 230.

[7] Barale, V., Larkin, D., Fusco, L., Melinotte, J.M. and Pittella, G. (1999) Ocean Project: The European Archive of CZCS Historical Data. International Journal of Remote Sensing, 20, 1201-1218. https://doi.org/10.1080/014311699212696

[8] Hakvoort, H., de Haan, J., Jordans, R., Vos, R., Peters, S. and Rijkeboer, M. (2002) Towards Airborne Remote Sensing of Water Quality in the Netherlands: Validation and Error Analysis. ISPRS Journal of Photogrammetry and Remote Sensing, 57, 171-183. https://doi.org/10.1016/S0924-2716(02)00120-X

[9] Kabbara, N., Benkhelil, J., Awad, M. and Barale, V. (2008) Monitoring Water Quality in the Coastal Area of Tripoli (Lebanon) Using High-Resolution Satellite Data. ISPRS Journal of Photogrammetry and Remote Sensing, 63, 488-495. https://doi.org/10.1016/j.isprsjprs.2008.01.004

[10] Snyder, J., Boss, E., Weatherbee, R., Thomas, A.C., Brady, D. and Newell, C. (2017) Oyster Aquaculture Site Selection Using Landsat 8-Derived Sea Surface Temperature, Turbidity, and Chlorophyll a. Frontiers in Marine Science, 4, 190. https://doi.org/10.3389/fmars.2017.00190

[11] Erkkila, A. and Kalliola, R. (2004) Patterns and Dynamics of Coastal Waters in Multi-Temporal Satellite Images: Support to Water Quality Monitoring in the Archipelago Sea, Finland. Estuarine, Coastal and Shelf Science, 60, 165-177. https://doi.org/10.1016/j.ecss.2003.11.024

[12] Kim, H.C., Son, S., Kim, Y.H., Khim, J.S., Nam, J., Chang, W.K., et al. (2017) Remote Sensing and Water Quality Indicators in the Korean West Coast: Spatio-Temporal Structures of MODIS-Derived Chlorophyll-a and Total Suspended Solids. Marine Pollution Bulletin, 121, 425-434. https://doi.org/10.1016/j.marpolbul.2017.05.026

[13] Biswas, S.N., Rakshit, D., Sarkar, S.K., Sarangi, R.K. and Satpathy, K.K. (2014) Impact of Multispecies Diatom Bloom on Plankton Community Structure in Sundarban Mangrove Wetland, India. Marine Pollution Bulletin, 85, 306-311. https://doi.org/10.1016/j.marpolbul.2014.04.015

[14] Chen, S.S., Han, L.S., Chen, X.Z., Li, D., Sun, L. and Li, Y. (2015) Estimating Wide Range Total Suspended Solids Concentrations from MODIS 250-m Imageries: An Improved Method. ISPRS Journal of Photogrammetry and Remote Sensing, 99, 58-69. https://doi.org/10.1016/j.isprsjprs.2014.10.006

[15] Fu, Y.Z., Xu, S.G., Zhang, C.K. and Sun, Y. (2018) Spatial Downscaling of MODIS Chlorophyll-a Using Landsat 8 Images for Complex Coastal Water Monitoring. Estuarine, Coastal and Shelf Science, 209, 149-159. https://doi.org/10.1016/j.ecss.2018.05.031

[16] Teixeira Pinto, B.C., Araujo, F.G., Rodrigues, V.D. and Hughes, R.M. (2009) Local 
and Ecoregion Effects on Fish Assemblage Structure in Tributaries of the Rio Paraiba do Sul, Brazil. Freshwater Biology, 54, 2600-2615. https://doi.org/10.1111/j.1365-2427.2009.02269.x

[17] Page, B.P., Kumar, A. and Mishra, D.R. (2018) A Novel Cross-Satellite Based Assessment of the Spatio-Temporal Development of a Cyanobacterial Hatinful Algal Bloom. International Journal of Applied Earth Observation and Geoinformation, 66, 69-81. https://doi.org/10.1016/j.jag.2017.11.003

[18] Li, Y., Zhang, Y.L., Shi, K., Zhou, Y.Q., Zhang, Y.B., Liu, X.H., et al. (2018) Spatiotemporal Dynamics of Chlorophyll-a in a Large Reservoir as Derived from Landsat 8 OLI Data: Understanding Its Driving and Restrictive Factors. Environmental Science and Pollution Research, 25, 1359-1374. https://doi.org/10.1007/s11356-017-0536-7

[19] Souza, N.M. and Wasserman, J.C. (1996) Diurnal Variation of Anionic Surfactants and Forms of Phosphorus in a Polluted Stream (Piratininga, Rio de Janeiro, Brazil). Toxicological \& Environmental Chemistry, 55, 173-181. https://doi.org/10.1080/02772249609358333

[20] Wright, D.B., Smith, J.A., Villarini, G. and Baeck, M.L. (2012) Hydroclimatology of Flash Flooding in Atlanta. Water Resources Research, 48.

https://doi.org/10.1029/2011WR011371

[21] Suguio, K. and Martin, L. (1978) Quaternary Marine Formations of the State of São Paulo and Southern Rio de Janeiro. Conference Quaternary Marine Formations of the State of São Paulo and Southern Rio de Janeiro, Sao Paulo, 11-18 September 1978, 55.

[22] Borelli, E. (2015) Dinâmica urbana e degradação ambiental do Litoral Norte Paulista, II Simpósio Internacional de Gestão de Projetos/Simpósio Internacional de Inovação e Sustentabilidade São Paulo, SP, Uninove. 1-17.

[23] Luchiari, M.T.D. (2002) Turismo e cultura caiçara no Litoral Norte paulista. In: Rodrigues, A.B., Ed., Turismo e desenvolvimento local, Hucitec, São Paulo, 136-154.

[24] Binsztok, J., Wasserman, J. and Romeu, T. (2010) Visibilidade e (In)visibilidade Construídas pelos “Dragões” da Exploração e Produção de Petróleo em Macaé-RJ. Anais XVI Encontro Nacional dos Geógrafos: Crise, práxis e autonomia: Espaços de resistência e de esperanças-Espaço de Socialização de Coletivos, Porto Alegre, RS, Associação dos Geógrafos Brasileiros, 1-7.

[25] Binsztok, J., Wasserman, J.C. and Romeu, T. (2010) Restruturação produtiva, modificações sócio-espaciais e exploração de petróleo no Brasil: O caso de Macaé, RJ. XI Coloquio Internacional de Geocritica. contrib. 102. Sociedade Internacional de Geocrítica, Facultad de Filosofía y Letras (Universidad de Buenos Aires), Buenos Aires, Argentina, 2-7 May 2010, 1-10.

[26] IBGE (2010) Demographic census 2010. Instituto Brasileiro de Geografia e Estatística-Comitê de Estatísticas Sociais, Brasília.

[27] de Souza Rolim, G., Paes de Camargo, M.B., Grosseli Lania, D. and Leite de Moraes, J.F. (2007) Classificação climática de Köppen e de Thornthwaite e sua aplicabilidade na determinação de zonas agroclimáticas para o estado de São Paulo. Bragantia, 66, 711-720. https://doi.org/10.1590/S0006-87052007000400022

[28] Carranzano, J., de€Jesús, T.L., Matías, F. and Wasserman, J.C. (2018) The Influence of Climate Change on the Intensity and Distribution of Rain in Four Rio de Janeiro (Brazil) Weather Stations. Ambiência, 14, 140-153.

[29] Marandola Jr., E., Marques, C., Paula, L. and Cassaneli, L.B. (2013) Crescimento 
urbano e áreas de risco no litoral norte de São Paulo. Revista Brasileira de Estudos de População, 30, 35-56. https://doi.org/10.1590/S0102-30982013000100003

[30] Bouillon, S., Abril, G., Borges, A.V., Dehairs, F., Govers, G., Hughes, H.J., et al. (2009) Distribution, Origin and Cycling of Carbon in the Tana River (Kenya): A Dry Season Basin-Scale Survey from Headwaters to the Delta. Biogeosciences, 6, 2475-2493. https://doi.org/10.5194/bg-6-2475-2009

[31] Paloczy, A., Brink, K.H., da Silveira, I.C.A., Arruda, W.Z. and Martins, R.P. (2016) Pathways and Mechanisms of Offshore Water Intrusions on the Espirito Santo Basin Shelf (18 Degrees S-22 Degrees S, Brazil). Journal of Geophysical Research: Oceans, 121, 5134-5163. https://doi.org/10.1002/2015JC011468

[32] Batista, S.S. (2016) Avaliação dos efeitos de ações antrópicas sobre o sistema costeiro de Ubatuba (SP) através de modelagem ambiental. Dissertation, USP, São Paulo.

[33] International Standards Organization (2015) ISO 14001:2015-Environmental Management Systems-Requirements with Guidance for Use. 3rd Edition, ISO, Geneva. 


\section{Appendix A}
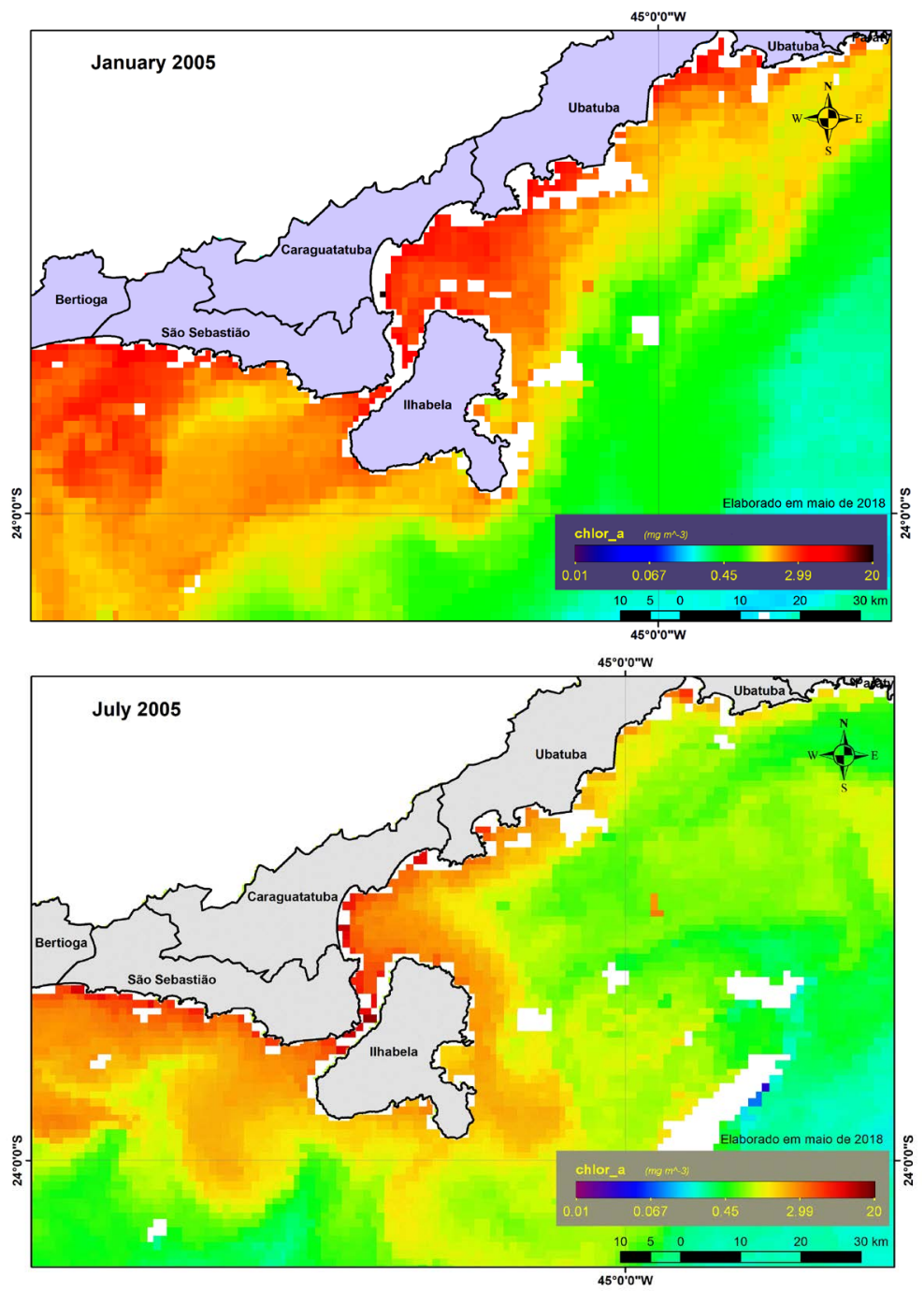

Figure A1. Satellite image of Chlorophyll a. January and July 2005.

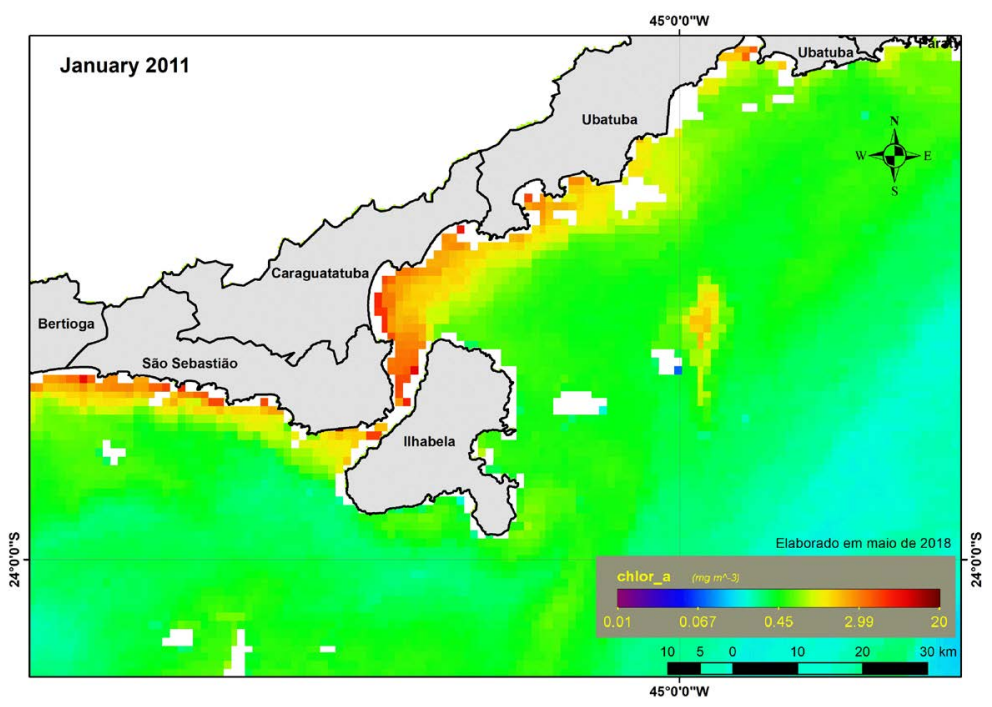




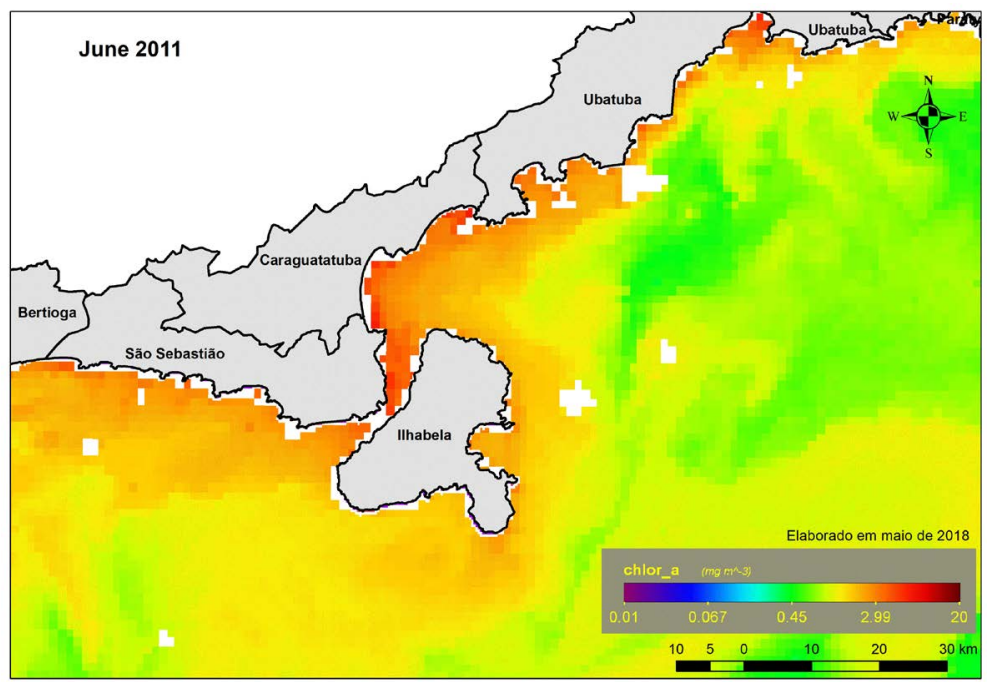

Figure A2. Satellite image of Chlorophyll a. January and June 2011.
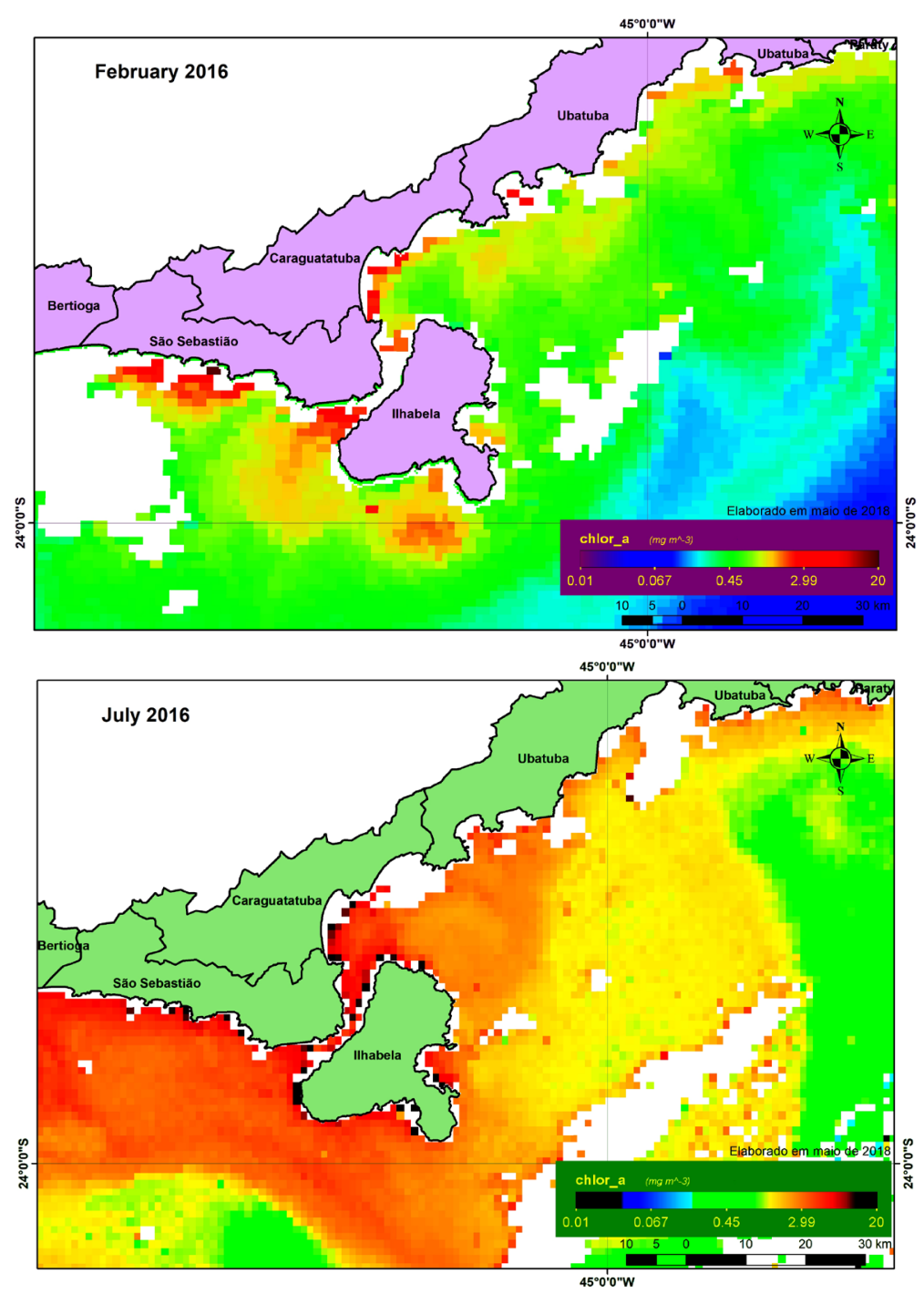

Figure A3. Satellite image of Chlorophyll a. February and July 2016. 

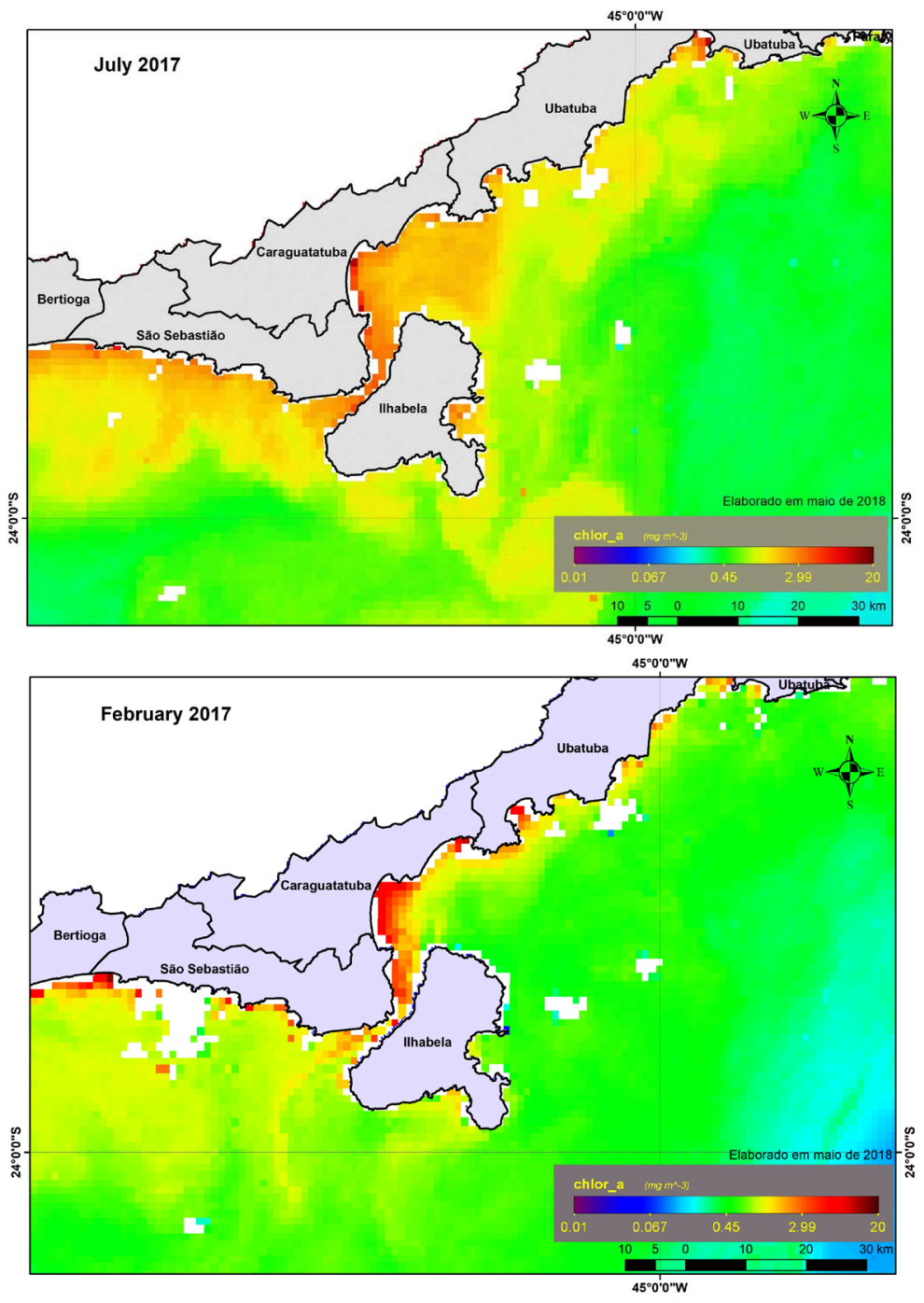

Figure A4. Satellite image of Chlorophyll a. February and July 2017.

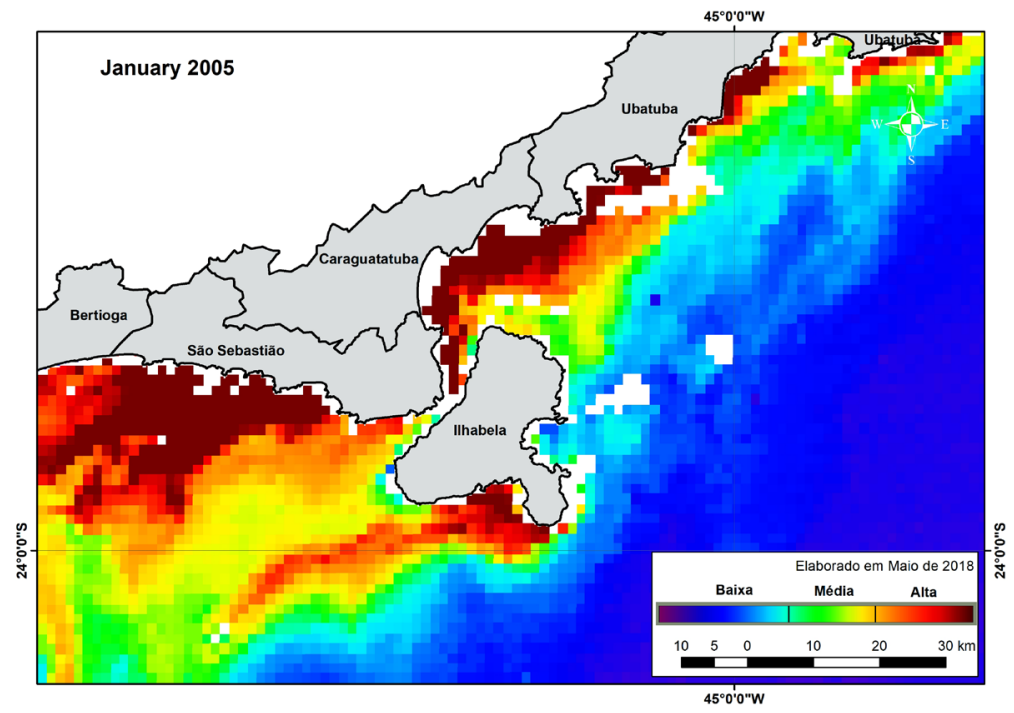

Figure A5. Satellite image of Turbidity. January 2005. 

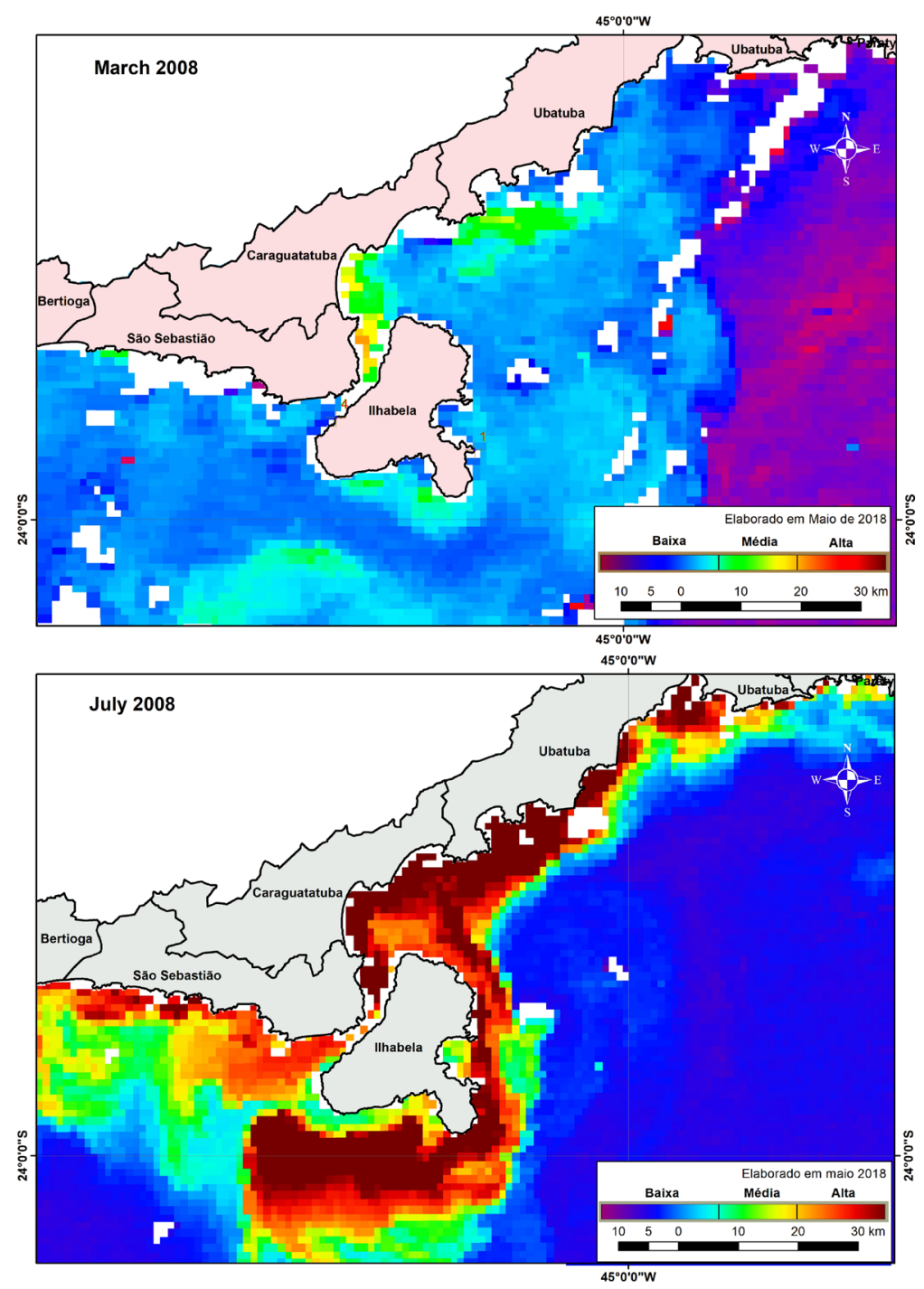

Figure A6. Satellite image of Turbidity. March and July 2008.

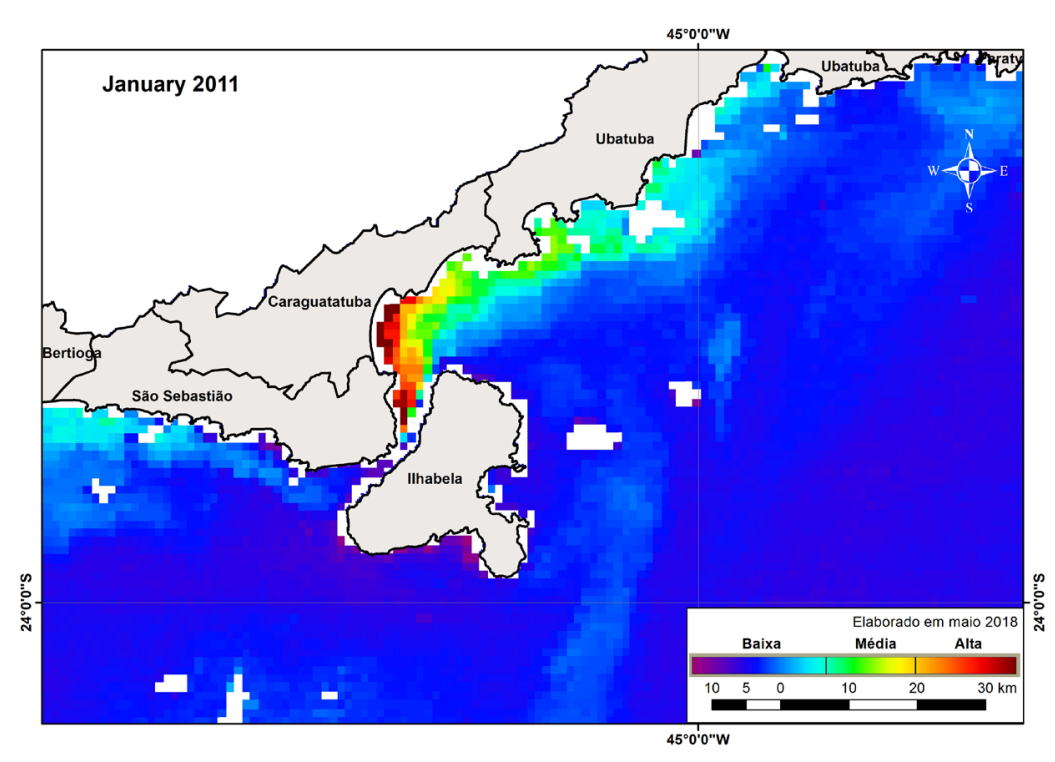




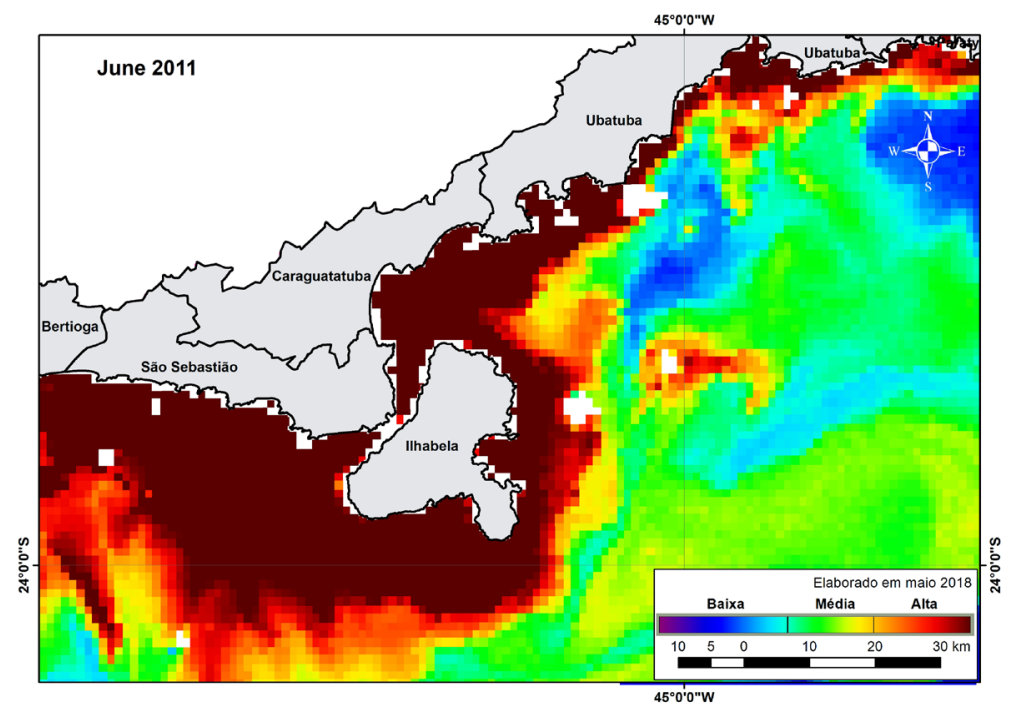

Figure A7. Satellite image of Turbidity. January and June 2011.
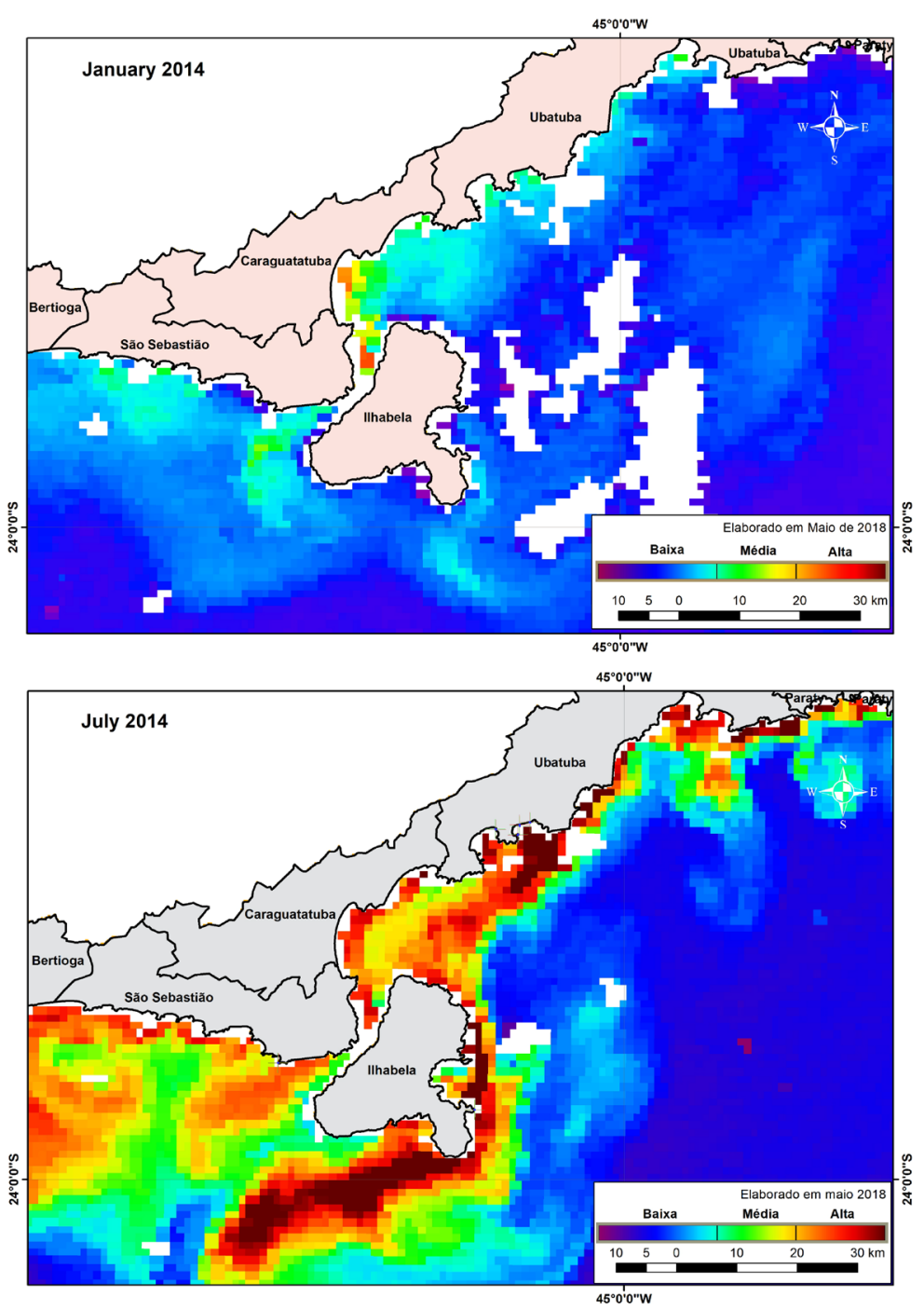

Figure A8. Satellite image of Turbidity. January and July 2014. 

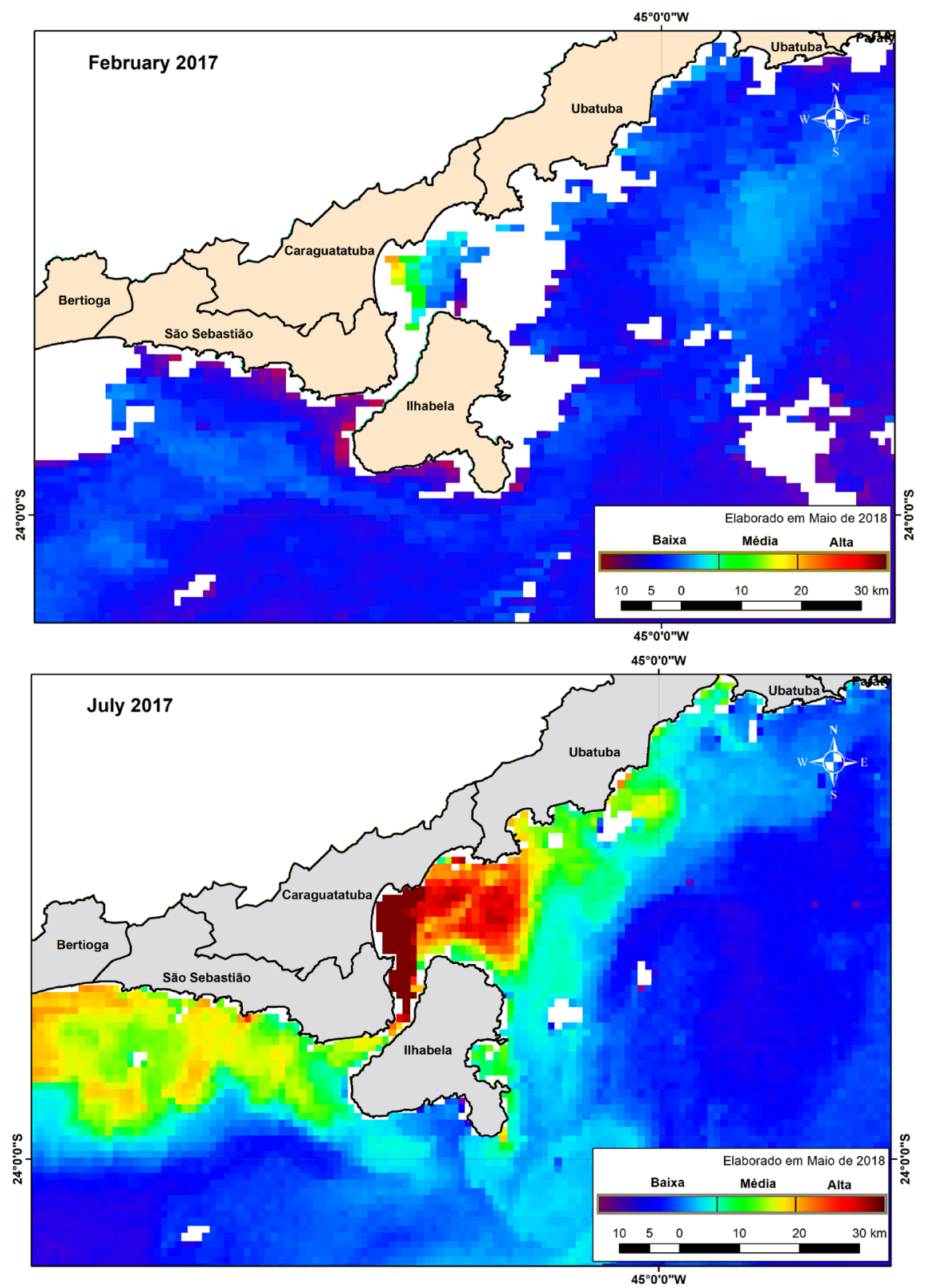

Figure A9. Satellite image of Turbidity. February and July 2017. 